\title{
Visit Time
}

National Cancer Institute

\section{Source}

National Cancer Institute. Visit Time. NCI Thesaurus. Code C83154.

The time at which a visit occurred. 